International Journal of Basic and Applied Sciences, $7(3)(2018) 48-54$
SPC
Website: $\begin{gathered}\text { www.sciencepubco.com/index.php/IJBAS } \\ \text { doi: } 10.14419 / j \text { ijbas.v7i3.14519 } \\ \text { Research paper }\end{gathered}$

\title{
Optimization conditions of alkaline protease production by Streptomyces sp.H1 isolated from red sea coastal region in submerged culture
}

\author{
Hind A. A. Al-Zahrani * \\ Biology Depart, Faculty of Sciences, University of Jeddah, Jeddah, Saudi Arabia \\ *Corresponding author E-mail: Haaalzahrani5@uj.edu.sa
}

\begin{abstract}
A potent alkaline protease producing strain characterized and identified as Streptomyces sp. H1 was isolated from soil around red sea shore. The enzyme was produced extracellulary in submerged culture revealed maximum level during early stationary phase. Alkaline protease showed the highest activity at incubation time, $\mathrm{pH}$ and inoculum size of 3 days, 9 and $8 \%$ respectively. Among different carbon sources beet molasses gave a maximum production followed by starch, sucrose and fructose. High yield of protease production was noticed with casein followed by peptone, yeast extract and ammonium sulphate. Furthermore, it was optimized with $7 \mathrm{~g} / \mathrm{l} \mathrm{NaCl} \mathrm{resulted} \mathrm{in} \mathrm{higher} \mathrm{level}$ of protease. Optimization of the process parameters resulted in about 3.4 fold increase in the alkaline protease. Partial purification of the crude enzyme was achieved by fractional precipitation using ammonium sulfate at $50 \%$ saturation. Due to the maximum production of protease in the presence of cheaper substrate as beet molasses, stability at alkaline $\mathrm{pH} 9$ and temperature up to $70 \mathrm{oC}$ besides salt tolerance make the strain and its enzyme useful in different industrial applications.
\end{abstract}

Keywords: 16S Rdna; Alkaline Protease; Optimization; Streptomyces SP; Submerged Culture.

\section{Introduction}

Besides the production of drugs, microorganisms serve as an excellent source for the synthesis of various useful industrial enzymes. Proteases are the most important group has wide applications as additive to detergents in several industrial processes (Suthindhiran, et. al., 2014). They catalyze the hydrolysis of protein into amino-acid especially alkaline type is increasingly finding potential future applications in pharmaceutical industry too (Singhal, et. al., 2012). Different kinds of microorganisms; bacteria, fungi, yeast, actinomycetes, in addition plants and mammalian tissues produced alkaline proteases (Mukesh, et. al., 2012 and El-Shafei, et. al., 2010). Moreover, microbial process may meet more easily the current market demand for industrial enzymes due to the rapid doubling time of microbes compared with plants or animals. The majority of microbial enzymes produced on a commercial scale are extracellular, and are potentially employed in industries because they exhibit stability to chemical and physical changes in the medium (Ramesh, et. al., 2009). Actinomycetes particularly Streptomyces are known to secrete multiple (greater) proteases in culture medium, which is generally regarded as safe with food and drug administration. Streptomyces spp., that have been reported to produce proteases include $\mathrm{S}$. claviligerus, S. griseus, S. rimonus, $\mathrm{S}$. thermoviolaceus and $\mathrm{S}$. thermovulgaris (Okpukpara and George-Okafor, 2016). As the composition of culture medium strongly influences enzyme production (Jayasree, et. al., 2009 and Arifuzzaman, et. al., 2010), therefore, this study was aimed in selecting novel alkaline protease -producing actinomycete and optimizing different fermentation parameters for obtaining high alkaline protease yield.

\section{Materials and methods}

\subsection{Isolation and screening of microorganisms}

Samples were collected from soil around red sea shore. For isolation of actinomycetes, starch casein agar medium was used and its composition was as follow: starch $15 \mathrm{~g}$; casein $5 \mathrm{~g}$; peptone $5.0 \mathrm{~g}$; beef extract $3.0 \mathrm{~g}$; NaCl $5.0 \mathrm{~g}$; Nalidixic acid $10 \mu \mathrm{l} / \mathrm{ml}$; nystatin 25 $\mu \mathrm{l} / \mathrm{ml}$, cyclohexamide $10 \mu \mathrm{l} / \mathrm{ml}$; agar $15 \mathrm{~g}$, distilled water $1000 \mathrm{ml}$ [8] . All the isolated actinomycetes were screened for protease production by streaking separately on $1 \%$ casein and gelatin agar and the plates were incubated at $32^{\circ} \mathrm{C}$ temperature. After 5 days, the plates were observed for clear zones caused by hydrolysis of casein and gelatin around the colonies. Among 20 actinomycetes, an isolate was selected as it produced highest proteolytic activity.

\subsection{Identification of the potent isolate}

\subsubsection{Phenotypic identification}

The strain was identified by morphological, cultural, physiological, and biochemical characteristics according to the methods described in International Streptomyces Project (ISP) (Shirling and Gottlieb, 1966). Color of aerial mycelium was determined from mature, sporulating aerial mycelia of the actinomycetes colonies on starch-casein agar media after 14 days at $30{ }^{\circ} \mathrm{C}$ (Pridham, 1964). Morphological observations of spore and mycelia were studied by light microscope through the oil immersion (1000×, Olympus) microscope done by cover slip culture method (Kawato and Shinobu, 1959) as well as scanning electron microscope (JEOL JSM 5300, JEOL 
Techniques Ltd., Japan). The observed structure was compared with Bergey's manual of Determinative Bacteriology (Bergey's, 2000) and the organism was identified.

\subsection{Molecular identification}

\subsubsection{DNA isolation and manipulation}

Two milliliters of the potent isolate spore suspension were inoculated into the starch-nitrate broth and incubated for 3 days on a shaker incubator at $200 \mathrm{rpm}$ and $30^{\circ} \mathrm{C}$ to form a pellet of vegetative cells (pre-sporulation). Then the culture was centrifuged for $10 \mathrm{~min}$ at 5000 ad the supernatant was discarded and the preparation of total genomic DNA was carried out (Sambrook, et. al., 1989).

\subsubsection{Amplification and sequencing of the $16 \mathrm{~S}$ rDNA gene}

The polymerase chain reaction (PCR) using primers designed to amplify $1500 \mathrm{bp}$ fragment of the 16S rDNA gene of the local actinomycete strain was performed. A total volume of $100 \mu \mathrm{l}$, which contained $1 \mu \mathrm{l}$ DNA, $10 \mu \mathrm{l}$ of $250 \mathrm{mM}$ deoxyribonucleotide 5'-triphosphate (dNTP's); $10 \mu$ PCR buffer, $3.5125 \mathrm{mM} \mathrm{MgCl}_{2}$ and $0.5 \mu 1$ Taq polymerase, $4 \mu 1$ of 10 pmol (each) with forward $16 \mathrm{~S}$ rRNA primer $27 \mathrm{f}$ ( 5 '-AGAGTTTGATCMTGCCTCAG-3') and reverse 16S rRNA primer 1492r (5'-TACGGYTACCTTGTTACGACTT-3') and water was added up to $100 \mu 1$. Amplification was conducted for 30 cycles of $1 \mathrm{~min}$ at $94^{\circ} \mathrm{C}, 1 \mathrm{~min}$ of annealing a $53^{\circ} \mathrm{C}$, and 2 min of extension at $72^{\circ} \mathrm{C}$. The PCR reaction mixture was then analyzed via agarose gel electrophoresis, and the remaining mixture was purified using QIA quick PCR purification reagents (Qiagen, USA). The purified PCR product was sequenced by using two primers, 518F; 5'-CCA GCA GCC GCG GTA ATA CG3' and 800R; 5'-TAC CAG GGT ATC TAA TCC-3' using a Terminator Cycle Sequencing kit (ABI Prism 310 Genetic Analyzer, Applied Biosystems, USA). Sequencing product was resolved on an Applied Biosystems model 3730XL automated DNA sequencing system (Applied BioSystems, USA).

\subsubsection{Sequence similarities and phylogenetic analysis}

The BLAST program (www.ncbi.nlm.nih.gov/blst) was employed in order to assess the degree of DNA similarity. Multiple sequence alignment and molecular phylogeny were evaluated using BioEdit software (Hall, 1999). The phylogenetic tree was displayed using the TREE VIEW program.

\subsection{Medium for protease production}

The entire study on nutritional factors affecting protease production was carried out in Erlenmeyer flasks $(250 \mathrm{ml})$ containing $50 \mathrm{ml}$ of the production fermentation medium: glucose $5 \mathrm{~g} / \mathrm{l}$; peptone, $10 \mathrm{~g} / \mathrm{l}$ $\left.\mathrm{NaCl}, 5 \mathrm{~g} / \mathrm{l} ; \mathrm{K}_{2} \mathrm{HPO}_{4}, 0.5 \mathrm{~g} / \mathrm{l} ; \mathrm{MgSO}_{4} .7 \mathrm{H}_{2} \mathrm{O}, 0.5 \mathrm{~g} / \mathrm{l}\right)$. The $\mathrm{pH}$ of the media was adjusted at [7]. For inoculation, sterile medium containing yeast extract $4 \mathrm{~g} / \mathrm{l}$, malt extract $10 \mathrm{~g} / \mathrm{l}$, dextrose $4 \mathrm{~g} / \mathrm{l}$ was prepared and inoculated with a fully sporulated slant of the producer isolate. Inoculated flask was shacked in an incubator at $200 \mathrm{rpm}$ and $32^{\circ} \mathrm{C}$. After about $48 \mathrm{~h}$ (at logarithmic phase), $1.5 \mathrm{ml}$ of the seed culture was transferred into $50 \mathrm{ml}$ of sterile production media and incubated at $32{ }^{\circ} \mathrm{C}$ for 6 days on a rotary shaker at $200 \mathrm{rpm}$. After incubation period, the cells were removed by centrifugation at 5000 rpm for $10 \mathrm{~min}$., and then the mycelium free supernatant was used as a crude enzyme for estimation of protease activity. The experiments were carried out in triplicate and the average values are presented.

\subsection{Optimization of culture conditions}

Various parameters were studied for maximum alkaline protease production in submerged culture include investigation of incubation time (1-6days), $\mathrm{pH}$ (7-11) and inoculum size (1-5 percent). The cultures were incubated at $32^{\circ} \mathrm{C}$ and analyzed for protease activity. 2.6.
Effect of different carbon and nitrogen sources on protease production

To test the effect of different carbon sources on protease production, glucose in the basal medium was substituted with $(0.5 \% \mathrm{w} / \mathrm{v})$ of fructose, starch, sucrose, beet molasses and glycerol which were separately added as a sole carbon. To test the effect of different nitrogen sources, peptone in the basal medium was substituted with $1 \% \mathrm{w} / \mathrm{v}$ of yeast extract, casein, ammonium sulphate, ammonium nitrate, sodium nitrate and urea. Whereas, a control represented by the production basal medium was performed at the same time. Media were inoculated and incubated at $32{ }^{\circ} \mathrm{C}$ for 6 days with shaking at $200 \mathrm{rpm}$.

\subsection{Enzyme assay}

Protease activity in the culture supernatant was determined using casein as a substrate [15]. To $3 \mathrm{ml}$ of $0.6 \%$ casein solution ( $\mathrm{pH} 9.0$, prepared in $10 \mathrm{mM}$ Tris- $\mathrm{HCl}$ buffer), $0.5 \mathrm{ml}$ of diluted enzyme solution was added and the reaction mixture was incubated at $40^{\circ} \mathrm{C}$ for $10 \mathrm{~min}$. The reaction was terminated by the addition of $3.2 \mathrm{ml}$ of a mixture of $0.11 \mathrm{M}$ Trichloroacetic acid, $0.22 \mathrm{M}$ sodium acetate and $0.33 \mathrm{M}$ acetic acid and the reaction mixture was allowed to stand for $15 \mathrm{~min}$ followed by centrifugation to separate the nonreacted casein at $5000 \mathrm{rpm}$ for $20 \mathrm{~min}$. The supernatant was mixed with $2.5 \mathrm{ml}$ of $0.4 \mathrm{~mol} / \mathrm{l} \mathrm{Na} 2 \mathrm{CO} 3$ and $1 \mathrm{ml}$ of 3-fold diluted FolinCiocalteu phenol reagent was added. The resulting solution was incubated at room temperature in the dark for $30 \mathrm{~min}$ and the absorbance of the blue color developed was measured $660 \mathrm{~nm}$ (Tsuchida, et. al., 1986 and Lowry, et. al., 1951) against a reagent blank using a tyrosine standard. One unit of protease activity is expressed as the amount of enzyme which converts $1.0 \mathrm{mg}$ of protein per $10 \mathrm{~min}$ at $40^{\circ} \mathrm{C}$.

\subsection{Determination of protein content}

To determine the protein content, a standard curve of protein concentration was generated using Coomassie Brilliant Blue (CBB) and bovine serum albumin (BSA) [17].The absorbance was plotted against the protein content. The protein content of the unknown sample was calculated from the standard curve.

\subsection{Partial purification of alkaline protease from culture filtrate}

The ammonium sulphate was added slowly to the supernatant containing the crude enzyme with stirring until the required saturation of ammonium sulphate was reached ranging from $35-80 \%$ saturation. The saturated enzyme solution was kept overnight at $4^{\circ} \mathrm{C}$. The precipitated protein obtained from each saturation was collected by centrifugation at $5000 \mathrm{rpm}$ for $30 \mathrm{~min}$ at $4^{\circ} \mathrm{C}$, dissolved in deionised water and dialysed for 2 days against phosphate buffer $0.1 \mathrm{M} \mathrm{pH}$ 7.0. Then the enzyme was assayed for its activity.

2.10. Effect of temperature on enzyme activity and stability The partially purified enzyme was stored at different temperatures ranging from 30 to $70^{\circ} \mathrm{C}$. The time of incubation of the samples varied from 30 to 60 minutes at $\mathrm{pH} 9$. After incubation, the samples were submitted to determination of protease activity.

\section{Results and discussion}

\subsection{Screening for protease activity}

Results showed that almost all actinomycete isolates were capable of hydrolyzing protein in agar media. A difference in protease activity of the tested isolates was observed, this is might be due to taxonomic differences between strains living in the same zone of isolation (Bradford, 1976 and Strzelczyk \& Szpotański, 1989). Out of the 20 colonies of actinomycetes screened, one isolate showed prominent proteolytic activity with maximum zone of clearance on 
casein and gelatin agar. The result obtained from the proteolytic assay revealed that actinomycetes isolate was found to have the highest potential for protease production. The result was similar to proteolytic activity obtained from Streptomyces pulveraceus (Jayasree, et. al., 2009). Actinomycetes, are known to be good protease producers particularly Streptomyces sp. (Al-Askar, et. al., 2015a). It was discovered that aerial mycelium formation and sporulation are related to the production of extracellular proteases (Kitadokoro, et. al., 1994).

\subsection{Identification of the isolate}

Based on colonial appearances, the powdery whitish gray colored isolate with highest proteolytic activity was a Gram positive (Korkare, et. al., 2004), filamentous organism showed no distinctive or diffusible pigments, produced mycelium, aerial hyphae and non-motile spores with filamentous colony margin. The isolate showed reflexible spore chain, spores appear abundantly, white in color, oval to cylindrical in shape, and smooth in surface (Fig.1). The cell wall hydrolysate contains LL-diaminopimelic acid with no characteristic sugars. Other characteristics of the selected strain were observed on the basis of morphological, physiological and biochemical tests are summarized in Table 1. Based on results of growth characterization, the isolate was identified as a species belonging to the genus Streptomyces (Holt, et. al., 1994).

The ability of the actinomycetes species mostly reported by Streptomyces which produce whitish gray colored colony with its mycelia, which has good hydrolytic properties (Jayasree, et. al., 2009).
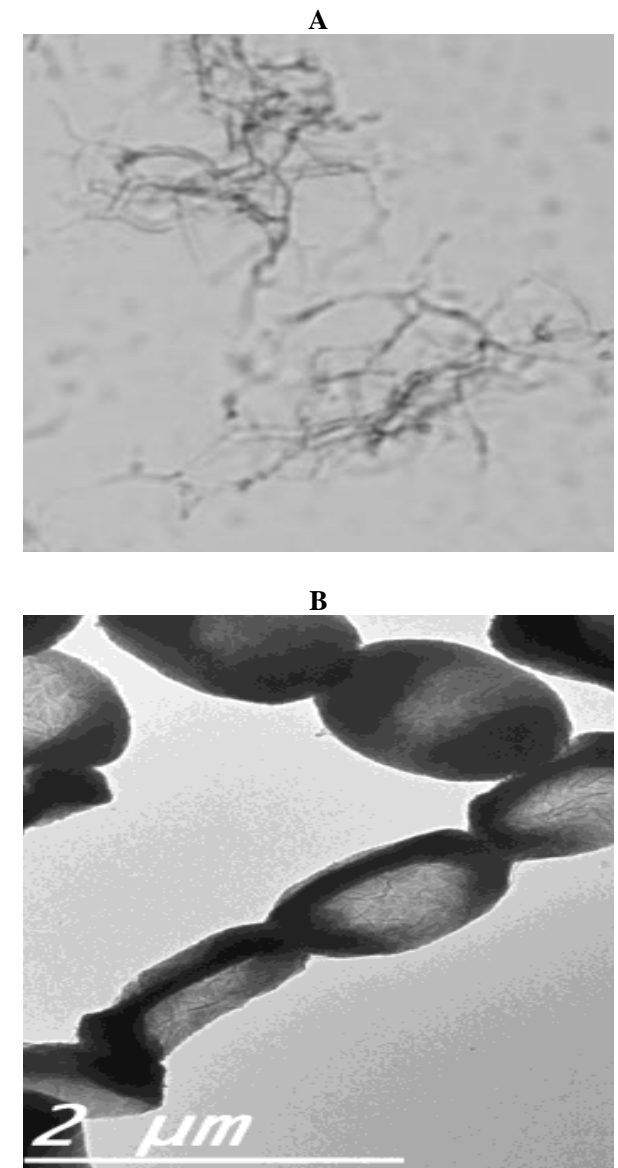

Fig. 1: A) Light Microscope 100X Magnification Showing Substrate and Aerial Hyphae and B) TEM Micrograph for Spores (Smooth) of the Potent Streptomyces Isolate Grown in Optimized Medium at $32{ }^{\circ} \mathrm{C}$ for 7 days.

Table 1: Growth Characteristics of the Streptomyces Isolate

\begin{tabular}{ll}
\hline Morphological characteristic & Result \\
\hline Grams stain & + \\
Cell morphology & Mycelial \\
Spore chains & rectiflexible \\
Spore surface & smooth \\
Colony color & White/ grey \\
Diffusible pigment & - \\
Motility & - \\
Cell wall hydrolysate & \\
Diaminopimelic acid (DAP) & + \\
Physiological and biochemical properties & \\
Hydrolysis of & \\
Starch & + \\
Protein & + \\
Casein & + \\
Citrate utilization test & + \\
Catalase & + \\
Gelatin Liquefaction & + \\
H2S production & + \\
Indole production & - \\
Nitrate reduction & - \\
Degradation of & + \\
D - glucose & + \\
L - rhamnose & \\
D - mannitol & + \\
Mannose & + \\
Dextrine & D - xylose \\
D - galactose & + \\
D - fructose & + \\
Lactose & + \\
Raffinose & - inositol \\
Cellulose & + \\
Sucrose & + \\
\hline & + \\
& + \\
\hline
\end{tabular}

After genomic DNA separation and purification, the sequence of the $16 \mathrm{~S}$ rRNA gene was determined in order to achieve the phylogeny. Search for similar sequences in the GenBank database and subsequent alignment of the retrieved sequences indicated that the DNA sequence showed high similarity $(99-100 \%)$ to the known 16S rRNA gene sequences from Streptomyces. Based on molecular taxonomy and phylogenetic analysis for precise genera identification, the strain was identified as Streptomyces sp and designated as Streptomyces sp. H1. A neighbor-joining tree based on 16S rRNA gene sequence revealed that the strain $\mathrm{H} 1$ belongs to the new species as it occupies a distinct phylogenetic position and different from other strains of Streptomyces (Fig. 3).

bp

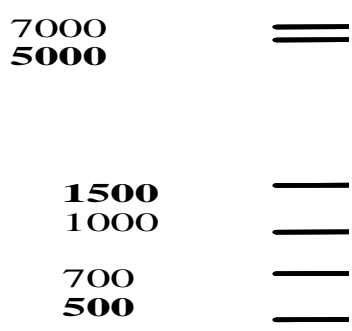

Fig. 2: M: Agarose Gel Electrophoresis for PCR Product: Kb-Standard, Lane 1: the Amplified Fragment Using Streptomyces's Primer for the Selected Isolate. 


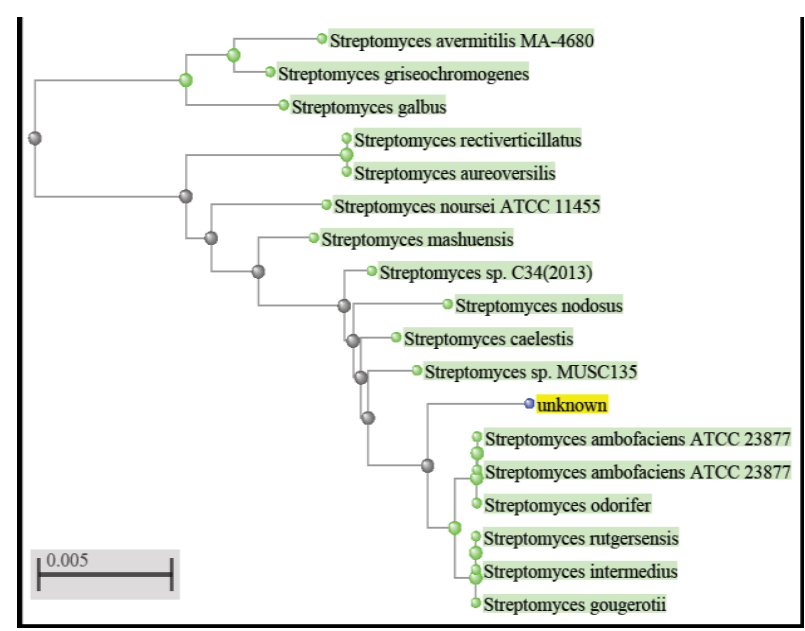

Fig. 3: Neighbour Joining Phylogenetic Tree of the Streptomyces Sp.H1 (The Unknown) Based on 16S Rrna Gene Sequences Shoing H1 Strain and the Nearest Related Taxa.

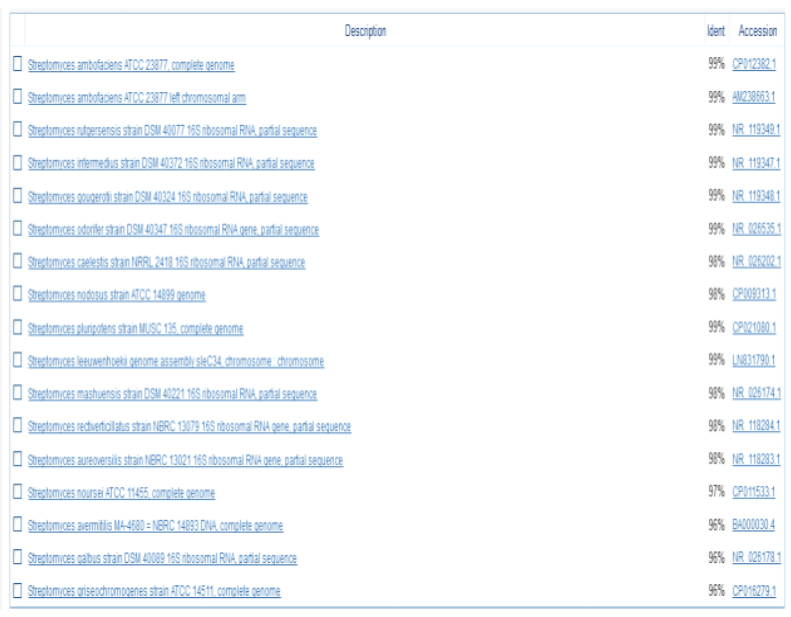

Fig. 4: Similarity of 16S RRNA Gene Sequences in the Genbank.

\subsection{Optimization of alkaline protease production}

\subsubsection{Effect of incubation period}

The study was carried out from 1-7 days incubation time and maximum enzyme formation $(230 \mathrm{u} / \mathrm{ml})$ was recorded with 3days of incubation period (Fig.5). The results revealed that there was an induction phase of proteolytic activity in the first $24 \mathrm{~h}$. During which considerable alkaline protease was synthesized. It was indicated by an activity of $22 \mathrm{u} / \mathrm{ml}$ and $58.36 \mathrm{u} / \mathrm{ml}$ in the first and second days respectively. The specific activity sharply increased to a maximum value in the third day of incubation as well. Following this phase, Both enzyme activity and specific activity decreased gradually from the $4^{\text {th }}$ day to the $7 \mathrm{t}^{\mathrm{h}}$ day. These results confirmed the observation reported previously which described an increase of protease production by Streptomyces cyanens and S. rimosus during log phase. This indicates that high level of alkaline protease production was observed during production of active biomass (Jayasree, et. al., 2009). This result was somewhat different from the other organism Streptomyces clavuligerus which starts synthesis of protease in the post-exponential phase of growth (Moreira, et. al., 2001).

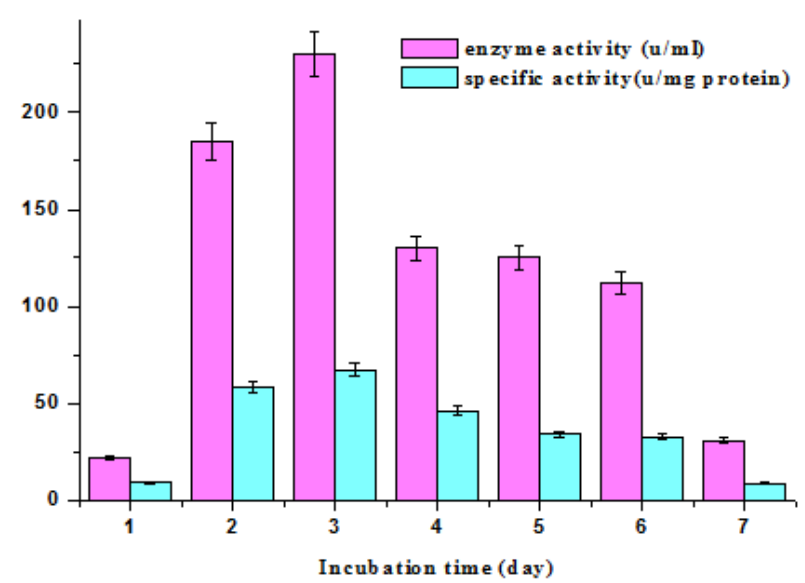

Fig. 5: Effect of Various Incubation Period on Protease Production by the Selected Strain Streptomyces Sp.H1. the Bars Indicate the Standard Deviation of Three Analyzed Replicates.

\subsubsection{Effect of initial $\mathrm{pH}$}

The effect of initial $\mathrm{pH}$ of the fermentation medium on alkaline protease production from the selected strain Streptomyces sp.H1 was studied. It was indicated that maximum enzyme activity $(244 \mathrm{u} / \mathrm{ml})$ and specific activity $(72.83 \mathrm{u} / \mathrm{mg}$ protein) occurred when the selected strain Streptomyces sp.H1 was cultured in a medium having pH 9 (Fig.6). These results are in accordance other observations reported when Str. clavuligerus grows optimally at pH 9.0. Similarly, it was reported that alkaliphilic Streptomyces sp. grows at an optimum pH 8-9 with scant growth at $\mathrm{pH} 7.0$ (El-Sayed, et. al., 2012). Therefore, optimized $\mathrm{pH} 9$ was applied in all he following experiments.

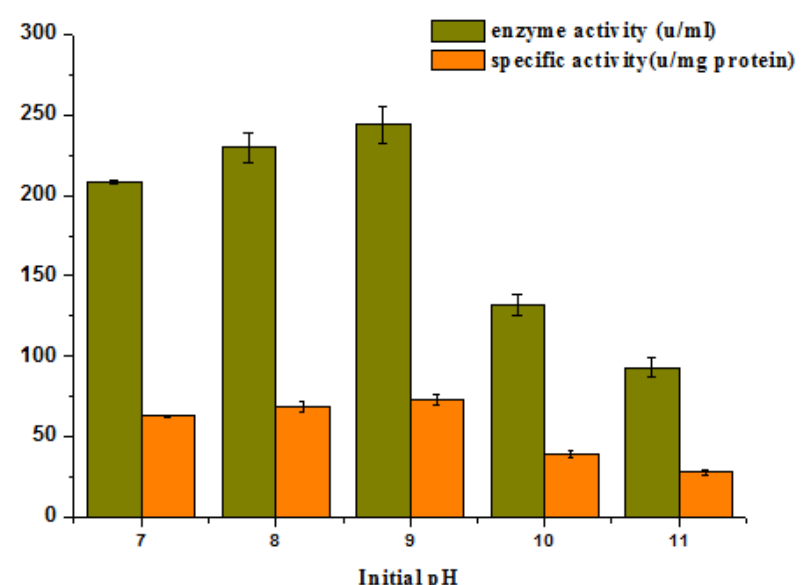

Fig. 6: Effect of Various Ph on Protease Production by the Selected Strain Streptomyces Sp.H1. the Bars Indicate The Standard Deviation of Three Analyzed Replicates.

\subsubsection{Effect of inoculum sizes}

The result revealed that, protease production and the specific activity were optimum when $8.0 \%(\mathrm{v} / \mathrm{v})$ of inoculum size was used recording $505.42 \mathrm{u} / \mathrm{ml}$ and $196.5 \mathrm{u} / \mathrm{mg}$ protein respectively. Higher inoculum sizes $10 \%$ decreased the protease production by $7 \%$ (Fig.7). Therefore, high cell densities in inoculum size over $8 \%$ might not necessarily give higher alkaline protease, it could result in nutrient depletion and the lack of oxygen and in the culture media and yield (Haritha, et. al., 2012). 


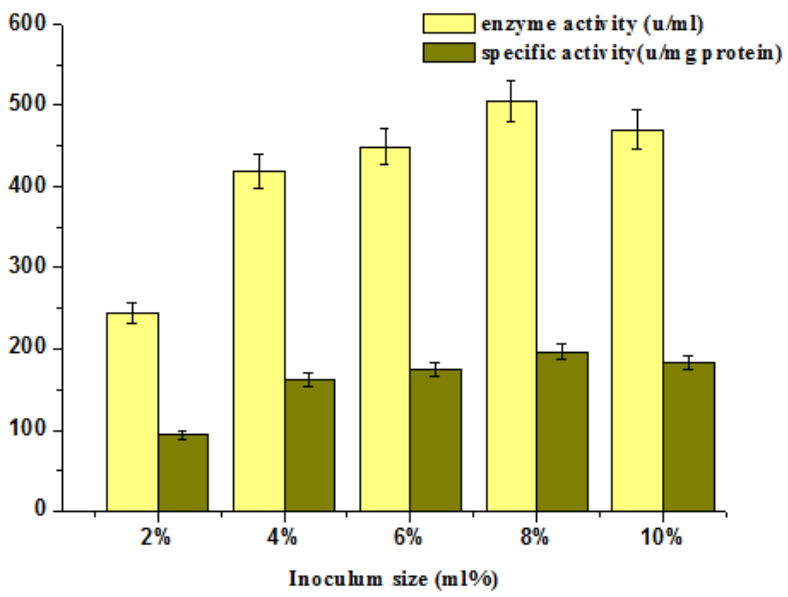

Fig. 7: Effect of Different Inoculum Percentages on Alkaline Protease Production by the Selected Strain Streptomyces Sp.H1. the Bars Indicate the Standard Deviation of Three Analyzed Replicates.

\subsubsection{Effect of different carbon sources}

Among various carbon sources used, beet molasses enhanced alkaline protease production (Fig. 8). It showed the highest activity of $720 \mathrm{u} / \mathrm{ml}$ corresponding to specific activity of $220 \mathrm{u} / \mathrm{mg}$ protein. Starch and sucrose were the second carbons that showed better activity than recorded in the control basal medium with optimized $\mathrm{pH}$ 9 and inoculum size $8 \%$ containing glucose as a carbon source. Sugars like fructose and glucose showed a moderate enzyme activity while glycerol showed the least activity (Fig.8). Similarly, results reported by Chi and Zhao (2003) revealed that different carbon sources have different influence on extracellular enzyme production by different strains. Sugar beet molasses is a well-known multifunctional nutrient contains sucrose which support slower growth than glucose but a higher rate of specific productivity. In addition, it contains many of the essential minerals and trace elements that may act as macro or micronutrient (Lotfy, 2007). According to these results, beet molasses will substitute glucose in the basal medium in the following experiments.

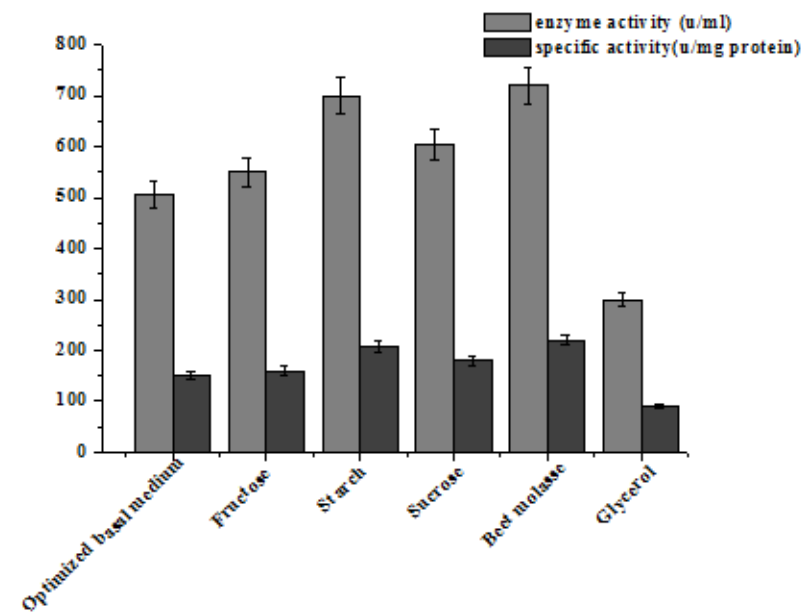

Fig. 8: Effect of Different Carbon Sources on Alkaline Protease Production by the Selected Strain Streptomyces Sp.H1. the Bars Indicate the Standard Deviation of Three Analyzed Replicates.

\subsubsection{Effect of different nitrogen sources}

The extracellular protease production could considerably be affected by the protein substrate and the composition of the medium (Al-Askar, et. al., 2015a). From the results, alkaline protease formation was enhanced by the organic nitrogen sources more than the tested inorganic nitrogen sources (Fig. 9). Among the organic nitrogen sources, Casein was found to enhance maximum enzyme production yield, enzyme activity of $(745 \mathrm{u} / \mathrm{ml})$ and specific activity of ( $208.9 \mathrm{u} / \mathrm{mg}$ protein) which was about $3.4 \%$ higher than peptone in the control basal medium. It was observed that, peptone followed by yeast extract, were found to have moderate enzyme production showed activity of 720 and $668 \mathrm{u} / \mathrm{ml}$, and specific activity of 201.7 and $187.25 \mathrm{u} / \mathrm{mg}$ protein respectively. Nitrogen source has been observed as another factor that influences protease production. Effect of the nitrogen source on extracellular protease produced by $\mathrm{S}$. clavuligerus was reported depend on the nature of the nitrogen source, and a transient decrease in protease titers was also observed (De Azeredo, et. al., 2006).

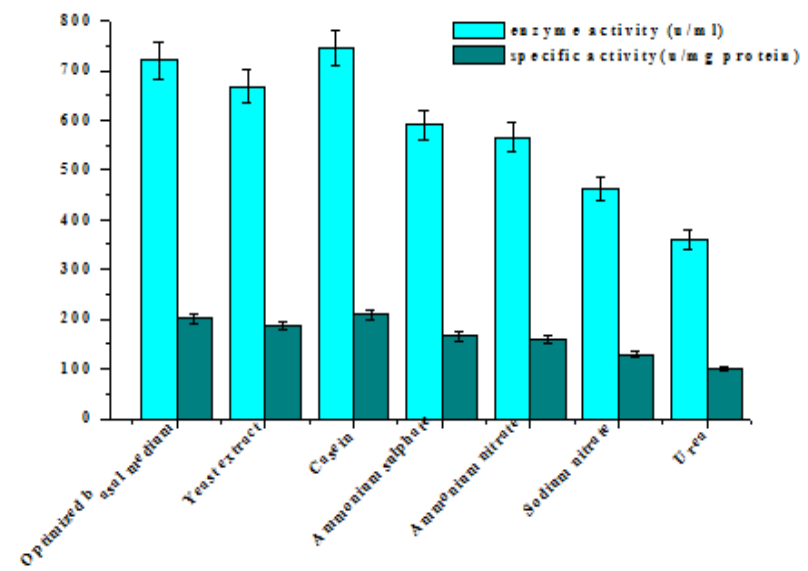

Fig. 9: Effect of Different Nitrogen Sources on Alkaline Protease Production by the Selected Strain Streptomyces Sp.H1. the Bars Indicate the Standard Deviation of Three Analyzed Replicates.

\subsubsection{Effect of NACL concentration the effect of salt on alkaline protease production was shown in}

Fig. 10. Maximum protease production was observed in the medium containing $7 \mathrm{~g} / \mathrm{l} \mathrm{NaCl}(772.6 \mathrm{u} / \mathrm{ml})$ at $72 \mathrm{~h}$ of incubation above this value alkaline protease was gradually reduced until $11 \mathrm{~g} / \mathrm{l}$ salt concentration. Salinity has pronounced effect on growth and enzyme production. The salt requirement of a truly halophilic Streptomonospora Alba sp. nov., was much more higher than that supported by the selected isolate under study. Similarly, although its presence was not essential for growth, Kocuria marina sp. nov., a novel actinomycete, tolerated up to $15 \% \mathrm{NaCl}$ in growth media (Thumar and Singh, 2007).

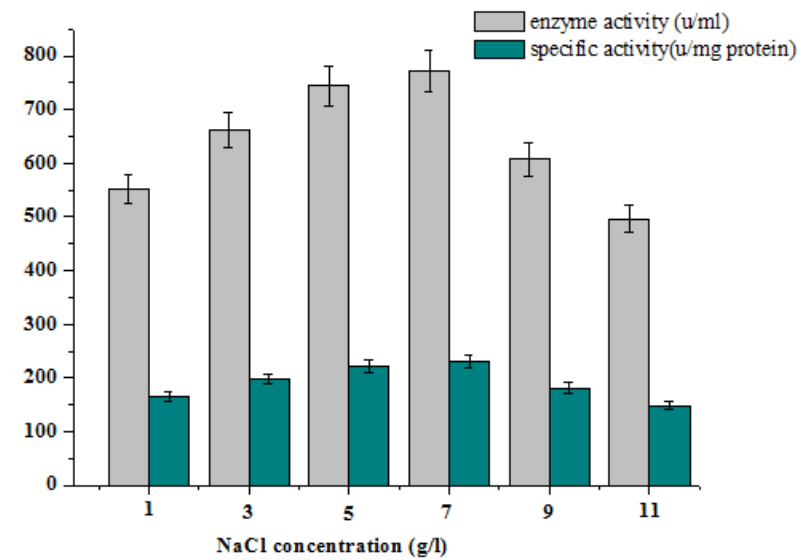

Fig. 10: Effect of Various Concentration of Nacl on Alkaline Protease Production by the Selected Strain Streptomyces Sp.H1. the Bars Indicate the Standard Deviation of Three Analyzed Replicates.

\subsubsection{Partial purification of alkaline protease}

The alkaline protease was partially purified from the culture filtrate of the selected strain Streptomyces sp.H1 using $\left(\mathrm{NH}_{4}\right)_{2} \mathrm{SO}_{4}$ precipitation (35-80\%). The enzyme fraction salted out at 50\%ammonium sulphate saturation was the most active fraction exihibited 14 fold purification (Fig.11). 


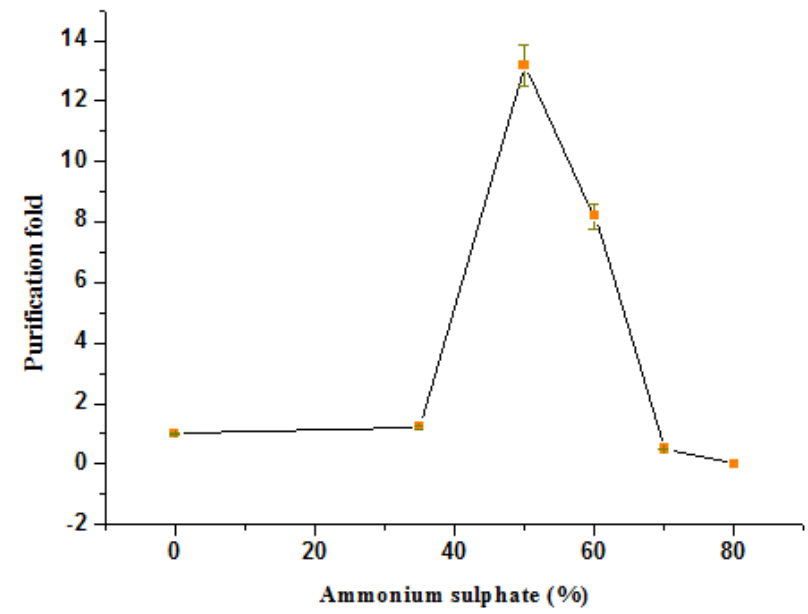

Fig. 11:.Partial Purification of Alkaline Protease with Ammonium Sulphate.

\subsubsection{Thermal stability of alkaline protease}

The stability of the alkaline protease produced by the selected strain Streptomyces sp.H1 was tested at temperatures $60^{\circ} \mathrm{C}$ and $70^{\circ} \mathrm{C}$ for $120 \mathrm{~min}$. the results showed that the enzyme was thermostable for at least 1 hour retaining about $30 \%$ and loose $70 \%$ of its activity after heating at $70^{\circ} \mathrm{C}$ (Fig. 12). Hence it is found that the alkaline protease form Streptomyces sp. H1 is thermostable and may be useful to various biotechnological processes.

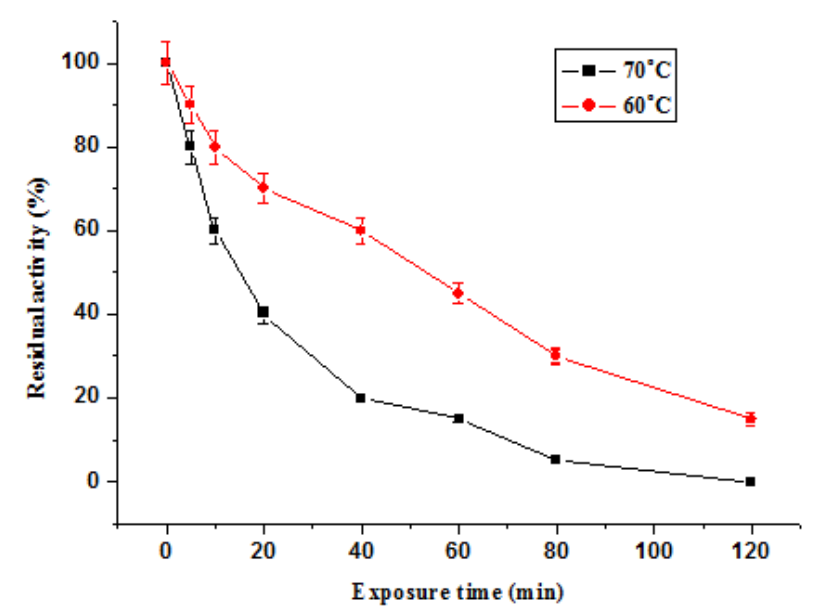

Fig. 12: Thermal Stability of Alkaline Protease at Different Incubation Temperatures $60^{\circ} \mathrm{c}$ and $70^{\circ} \mathrm{c}$.

\section{Conclusion}

In the present study, an actinomycete isolated from soil around red sea costal region having higher protease activity was selected for characterization and identification. The organism was identified as Streptomyces sp.H1. The use of low-cost carbon source beet molasses in the growth medium for production of this alkaline protease would significantly reduce the cost of enzyme production. The alkaline protease produced by the selected strain is thermostable can retain its activity at $70^{\circ} \mathrm{C}$ for 1 hour. These properties have a relevant economical and environmental impact in biotechnological applications.

\section{References}

[1] Suthindhiran K, Jayasri M, Dipali D and Prasar A (2014).Screening and characterization of protease producing actinomycetes from marine saltern. Journal of Basic Microbiology, 54(10): 1098-1109. https://doi.org/10.1002/jobm.201300563.
[2] Singhal P, NigamV K, Vidyarthi AS (2012). Studies on production characterization and applications of microbial alkaline proteases. International Journal of Advanced Biotechnology Research, 3: 653669.

[3] Mukesh Kumar DJ, Premavathi V, Govindarajan N, Balakumaran MD, Kalaichelvan PT (2012). Production and purification of alkaline protease from Bacillus sp. MPTK 712 isolated from dairy sludge. Global Veterinaria, 8: 433-439.

[4] El-Shafei H, Abdel-Aziz M, Ghali M and Abdalla A. (2010). Proceeding of Fifth Scientific Environmental Conference, ZagazigUniv, 125-142.

[5] Ramesh S, Rajesh M and Mathivanan N (2009). Characterization of a thermostable alkaline protease produced by marine Streptomyces fungicidicus MML1614. Bioprocess and Biosystems Engineering, 32: 791. https://doi.org/10.1007/s00449-009-0305-1.

[6] Okpukpara O B and George-Okafor U O (2016).Production of Thermostable Alkaline Protease from Streptomyces sp-A54. Nigerian Journal of Biotechnology, 31: $88 \quad-\quad 95$. https://doi.org/10.4314/njb.v31i1.12.

[7] Jayasree D, Sandhya Kumara TD, Kavi Kishor PB, Vi- jaya Lakshmi M, Lakshmi Narasu M. (2009). Optimization of production protocol of alkaline protease by Streptomyces pulvereceus. International JRI of Science and Technology, 1: 79- 82.

[8] Arifuzzaman M, Khatun M R and Rahman H (2010). Isolation and screening of actinomycetes from sundarbans soil for antibacterial activity. African Journal of Biotechnology, 9:4615-4619.

[9] Shirling EB, Gottlieb D (1966). Methods for characterization of Streptomyces species. International journal of systematic bacteriology, 16: 313-340. https://doi.org/10.1099/00207713-16-3-313.

[10] Pridham TG (1964). Color of Streptomyces: report of an international workshop on determination of color of Streptomyces. Applied Microbiology, 13: 43-6.

[11] Kawato M, Shinobu R (1959). Cover slip culture of Streptomyces herbaricolour nov. Sp. supplement; a simple technique for the microscopic observation. Mem. Osaka University, Lib. Art. Educ. 8: 114-119.

[12] Bergey's manual of determinative bacteriology (2000). Actinomycetales. $9^{\text {th }}$ edition.

[13] Sambrook J, Fritsch E F, Maniaties T (1989) Molecular Cloning: A Laboratory Manual second Cold. Spring, Harbor Laboratory press, Cold Spring Harbor, New York, USA.

[14] Hall TA (1999). BioEdit: a user-friendly biological sequence alignment editor and analysis program for Windows 95/98/NT. Nucleic Acids Symposium Series, 41: 95-98.

[15] Tsuchida O, Yamagota Y, Ishizuka J, Arai J, Yamada J, Takeuchi M, Ichishima E (1986). An alkaline protease of an alkalophilic Bacillus sp. Current Microbiology, 14:7-12. https://doi.org/10.1007/BF01568094.

[16] Lowry OH, Rosebrough NJ, Farr AL, Randall RJ. (1951). Protein measurement with Folin phenol reagent. Journal of Biological Chemistry, 193:265-275.

[17] Bradford M M (1976). A rapid and sensitive method for the quantitation of microgram quantities of protein utilizing the principle of protein-dye binding. Analytical Biochemistry, 72:248-254. https://doi.org/10.1016/0003-2697(76)90527-3.

[18] Strzelczyk E and Szpotański T (1989). Cellulolytic and pectolytic activity of streptomycetes isolated from root-free soil, rhizosphere and mycorrhizosphere of pine (Pinus sylvestris L.). Biology and Fertility of Soils, 9: 268-272. https://doi.org/10.1007/BF00336238.

[19] Al-Askar, A. A., Rashad, Y. M., Hafez, E. E., Abdulkhair, W. M., Baka, Z. A., \& Ghoneem, K. M. (2015a). Characterization of alkaline protease produced by Streptomyces griseorubens E44G and its possibility for controlling Rhizoctonia root rot disease of corn. Biotechnology \& Biotechnological Equipment, 29(3), 457-462. https://doi.org/10.1080/13102818.2015.1015446.

[20] Kitadokoro K, Tsuzuki H, Nakamura E, Sato T, Teraoka H (1994). Purification, characterization, primary structure, crystallization and preliminary crystallographic study of a serine proteinase from Streptomyces fradiae ATCC 14544, European Journal of Biochemistry, 220: (1) 55-61. https://doi.org/10.1111/j.14321033.1994.tb18598.x.

[21] Korkare CR, Mahadik KR, Kadam SS, Chopade BA (2004) Isolation, characterization and antimicrobial activity of marine halophilic Actinopolyspora species AH1 from the West coast of India. Current Sciences, 86593-597.

[22] Holt JG, Krieg NR, Sneath PH, et al. Group 19. Regular, non-sporing Gram-positive rods. In: Hensyl WR (ed), editor (1994). Bergey's manual of determinative bacteriology. Ninth ed. Baltimore: Williams \& Wilkins Inc. 565-70. 
[23] Moreira K A, Cavalcanti M T, Duarte H S, Tambourgi E B, Silva VL, Porto AN L, Filho J L (2001). Partial characterization of proteases from Streptomyces clavuligerus using an inexpensive medium. Brazilian Journal of Microbiology, 32:23-28. https://doi.org/10.1590/S1517-83822001000300010.

[24] El-Sayed E M, Moataza M S, Hassan M. A, Mohsen H S, and Helmy M. H (2012). Optimization Conditions of Extracellular Proteases Production from a Newly Isolated Streptomyces Pseudogrisiolus NRC-15. E-Journal of Chemistry, 9: (2) 949-961. https://doi.org/10.1155/2012/168540.

[25] Haritha R, SivaKumar K, Swathi A, Jagan Mohan YSYV and Ramana T (2012). Characterization of marine Streptomyces carpaticus and optimization of conditions for production of extracellular protease. Microbiology Journal, 2: 23-35. https://doi.org/10.3923/mj.2012.23.35.

[26] Chi Z M and Zhao S Z (2003). Optimization of medium and cultivation conditions for pullulan production by new pullulan-producing yeast strain. Enzyme and Microbial Technology, 33: 206-211. https://doi.org/10.1016/S0141-0229(03)00119-4.

[27] Lotfy WA (2007). Production of cephalosporin C by Acremonium chrysogenum grown on beet molasses: Optimization of process parameters through statistical experimental designs. Research Journal of Microbiology, 2: 1-12. https://doi.org/10.3923/jm.2007.1.12.

[28] De Azeredo LAI, De Lima MB, Coelho RRR and Freire DMG (2006). A low-cost fermentation medium for thermophilic protease production by Streptomyces sp 594 using feather meal and corn steep liquor. Current Microbiology, 53: 335-339. https://doi.org/10.1007/s00284-006-0163-x.

[29] Thumar JT, Singh SP (2007). Secretion of an alkaline protease from salt-tolerant and alkaliphilic, Streptomyces clavuligerus strain Mit1. Brazilian Journal of Microbiology, 38:1-9 https://doi.org/10.1590/S1517-83822007000400033. 